\title{
Genetic Diversity of Simulium damnosum complex Onchocerciasis Vector and its Influence on Entomological Monitoring in the West of Côte d'Ivoire
}

\author{
Siriki Simaro,
}

Université Jean Lorougnon Guédé,

Unité de Formation et de Recherche en Agroforesterie, Daloa, Côte d'Ivoire

Mathurin Koffi,

Université Jean Lorougnon Guédé,

Unité de Formation et de Recherche en Environnement, Daloa, Côte d'Ivoire

\section{Mahama Toure,}

Université Jean Lorougnon Guédé,

Unité de Formation et de Recherche en Agroforesterie, Daloa, Côte d'Ivoire

Bernardin Ahouty,

Université Félix Houphouët-Boigny,

Unité de Formation et de Recherche de Biosciences, Abidjan, Côte d'Ivoire

\section{Ibrahim Konate,} Abiba Sanogo Tidou,

Université Jean Lorougnon Guédé,

Unité de Formation et de Recherche en Agroforesterie, Daloa, Côte d'Ivoire

Doi:10.19044/esj.2019.v15n36p106 URL:http://dx.doi.org/10.19044/esj.2019.v15n36p106

\begin{abstract}
In West Africa, Onchocerca volvulus, the causative pathogen of human onchocerciasis, is transmitted by sibling species of the Simulium damnosum complex. Little is known about blackfly intraspecific variability and its consequences on vectorial capacity in Côte d'Ivoire. This study reports the use of microsatellite markers to study the genetic profile and evaluate the gene flow between populations of $S$. damnosum s.l from three (3) different epidemiological facies in western Côte d'Ivoire, fifteen years after the end of onchocerciasis control program. Adult flies were collected on human attractants from $07: 00$ to $18: 00$ hours for three consecutive days by site, from December 2016 to October 2017. Four (4) microsatellite loci were used to characterize individuals from these populations. The four (4) loci were polymorphic with 13.25 alleles per locus. Two (2) specific alleles (190 bp and $290 \mathrm{bp}$ ), were reveal abundant with respective frequencies of $0.46 \%$ and 0.58
\end{abstract}


$\%$. A significant heterozygosity deficiency and low genetic differentiation $\left(\mathrm{F}_{\mathrm{ST}}\right.$ $=0.046, P=0.024$ ) have been observed for all the populations. The genetic analysis showed significant deviation from Hardy-Weinberg and significant heterozygosity deficiencies. Then, the great interspecific variability would be a general characteristic in S. damnosum s.l. At last, a probable evolution of the invasive strains of $S$. damnosum would have occurred in these localities. This study has shown significant deviation from Hardy-Weinberg and significant heterozygosity deficiencies in the populations of the three localities. The loci give independent estimate genetic parameters. The H3-4 locus to a low genetic differentiation between the populations.

Keywords: Onchocerciasis, Simulium Damnosum S.L, SSR Markers, Polymorphism, Genetic Differentiation

\section{Introduction}

Human onchocerciasis, or river blindness, results from infection with the filarial parasite Onchocerca volvulus. In West Africa, the incidence of blindness due to infection with $O$. volvulus is much higher in savannah than in forest areas (Prost, 1980). The rate of blindness can reach up to $15 \%$ in savannah, whereas in forest zones, ocular manifestations of the disease are less severe, with a much lower degree of blindness (Duke, 1990). In West Africa, blackflies (Diptera: Simuliidae) of the Simulum damnosum complex serve as vectors for O. volvulus (Prost, 1980). From 1968, the international community mobilized human financial resources, material and technical to fight against this disease (Hougard et al., 2001). Then, from 1974 to 1990, the World Health Organization set up a vast onchocerciasis control program called OCP (WHO, 2002), which partly covered the endemic countries of West Africa. This strategy has reduced the transmission of the disease below the threshold for a public health problem in the majority of treated areas of covered countries, including Côte d'Ivoire (WHO / APOC ; Sightsavers, 2011). However, after stopping of OCP activities in 2002, Côte d'Ivoire was unable to conduct regular control activities because of the socio-political crisis which had just begin in September 2002. The interruption of larviciding treatments in vector control has certainly exposed resident populations to more and more abundant flies bites (WHO, 2002). OCP objective did not aim the eradication of the parasite and its vector and risk factors for recrudescence of the disease do still exist (Adjami et al., 2006). Therefore, the knowledge of the biological characteristics of $S$. damnosum s.l populations in view of climatic and environmental changes, but also the determination of the differentiation scale and the estimation of gene flow between populations is necessary. A wide range of molecular markers has been used for population studies. These include chromosomal inversions, allozymes, random amplified DNA 
polymorphisms, mitochondrial DNA sequences, and microsatellite loci analysis (Simard et al., 1999). Microsatellites are informative polymorphic DNA markers that are widely used to examine genetic diversity in the population of anopheles funestus (Cohuet et al., 2005), Aedes aegypti (Ravel et al., 2001 ; Ravel et al., 2002), Triatoma dimidiate (Anderson et al., 2001), Glossina palpalis (Solano et al., 1999), and Simulium damnosum s.l (Dumas et al., 1998). In this study we focus on microsatellite to dicipher the genetic diversity of $S$. damnosum s.l and evaluate the gene flow between populations of $S$. damnosum s.l in the context of climate and environmental changes.

\section{Material and Methods}

\section{Capture biting adult females of $S$. damnosums s.l.}

The classical capture method at human's bait (Le Berre, 1966 ; Philippon, 1977 ; Simaro et al., 2019) was used for collection of blackflies. A team of two people accomplished the capture of blackflies, one hour per person. The daily collected specimens was separated into clockwise period, and the flies capture tube containing one fly per tube, were labeled with the location, date and time of capture. The catches were made from 7 am to $6 \mathrm{pm}$ for 3 days by site. One site per locality was investigated and the individuals capturing were located $20 \mathrm{~m}$ from the river. Specimens were collected from December 2016 to October 2017.

\section{Morphological identification of female blackflies}

Morphological parameters such as antenna and bristles of the wing tuft colors ; the colors of the arculus ; the scutellum bristles; the first article of the anterior paw or procoxa and the bristles of the $9^{\text {th }}$ abdominal tergite were examined (Quilievéré., 1976 ; Simaro et al., 2019). The combined analysis of these parameters made it possible to identify savana female blackflies $(S$. damnosum ss and S. sirbanum), and forest females (S. yahense, S. sanctipauli, S. squamosum and S. soubrenses).

\section{DNA extraction from blackflies specimans}

Simulium damnusum s.l DNA was extracted from the whole body of adult female, according to a protocol based on $\mathrm{NaCl}$ buffer and adapted by the Research Unit of Genetics and Molecular Epidemiology (URGEM) of Jean Lorougnon Guede University. Briefly, the blackflies were manually crushed in a $1.5 \mathrm{ml}$ eppendorf tube containing $200 \mu \mathrm{l}$ of red blood cell lysis buffer. The mixture was then incubated at $56{ }^{\circ} \mathrm{C}$ for $1 \mathrm{~h}$ to lyse the proteins. A centrifugation at $12000 \mathrm{rpm}$ for $30 \mathrm{~min}$ permit to recover the solubilized DNA in the aqueous phase. The DNA is then precipitated in $200 \mu \mathrm{l}$ of absolute ethanol and then deposited by centrifugation for 20 minutes at $12000 \mathrm{rpm}$. 
The DNA deposit is then dried at room temperature overnight and resuspended in $75 \mu \mathrm{l}$ of TE buffer.

\section{DNA amplification with microsatellite markers}

Primers developed previously for S. damnosum s.l (Dumas et al., 1998) were used for Polymerase chain reaction (PCR) (Table 1). PCR was carried in $50 \mu \mathrm{l}$ final volumes, containing $2.5 \mu \mathrm{l}$ of $\mathrm{MgCl}_{2}$ with $10 \mathrm{X}$ reaction buffer, $1.5 \mu$ l of desoxyribonucleotide (dNTP $200 \mu \mathrm{M}), 1 \mu \mathrm{l}$ of each primer, 1 units of Taq DNA polymerase, $2.5 \mu$ of ADN sample and $16.3 \mu 1$ molécular water. After an initial denaturation at $92{ }^{\circ} \mathrm{C}$ for $5 \mathrm{~min}$, samples were processed through 40 cycles consisting of a denaturation step at $92{ }^{\circ} \mathrm{C}$ for $30 \mathrm{~s}$, an annealing step at $50{ }^{\circ} \mathrm{C}$ for $30 \mathrm{~s}$, and an extension step at $72{ }^{\circ} \mathrm{C}$ for $1 \mathrm{~min}$. The final elongation step was lengthened to $10 \mathrm{~min}$. Amplification products were checked by electrophoresis on $2 \%$ agarose gels immersed in $0.5 \mathrm{X}$ TBE buffer. $5 \mu \mathrm{l}$ of each amplified sample is mixed with $2 \mu \mathrm{l}$ of loading buffer (glycerol $50 \%$, bromophenol blue $0.2 \%$, xylene cyanol $0.2 \%$, EDTA pH 8 0.2M). A ФX174 size marker was used to quantify allele size. After 45 minutes of electrophoretic migration, the gel is visualised with a gel viewer (BioDOC-IT System) under UV light.

Table 1: Microsatellite loci, forward and reverse primer sequences.

\begin{tabular}{|c|c|c|c|c|}
\hline $\begin{array}{c}\text { Locu } \\
\text { s }\end{array}$ & Repeat sequence & Primers Sequence (5' 3') & Designation & $\begin{array}{c}\text { Product } \\
\text { length (bp) }\end{array}$ \\
\hline 60.1 & $(\mathrm{GT})$ AT(GT)AT(GT) $)_{10}$ & CCCATTTGCCAGTTGAGGTGA & SS1 & 975 \\
& & CCCGTCAACATTGTGGCTACG & SS2 & \\
\hline 64.2 & $(\mathrm{GT}) \mathrm{GC}(\mathrm{GT})_{10}$ & ATCATGACGAGGACGCACTC & SS3 & 510 \\
& & TACGCACACATTTTTCTATTTC & SS4 & \\
\hline 7.4 & $(\mathrm{GT})_{11} \mathrm{TT}(\mathrm{GT})$ & CGCTAACGCTGTGCAATATTG & SS7 & 270 \\
& & TGACGAACTTTGGGACGACA & SS8 & \\
\hline $\mathrm{H} 3-4$ & $(\mathrm{CAG})_{2}(\mathrm{CAA})_{10}(\mathrm{CAG})$ & CGACAACGTGTCTCGACAAA & SS9 & 500 \\
& & CGAAAACAACATACGAAGGG & SS10p & \\
\hline
\end{tabular}

\section{Data analysis}

Test for linkage disequilibrium and Genetic variability parameters for each population (number of distinct alleles, observed and expected heterozygosities under Hardy-Weinberg equilibrium), were conducted using GENETIX software, version 4.05.1 (Belkhir et al., 2004). The Fstat software version 2.6.4 (Goudet, 2003), is used to estimate the heterozygosity deficiencies of individuals in their sub-population (FIs), and simulated distribution of heterozygosity between a pair of populations ( $\left.\mathrm{F}_{\mathrm{ST}}\right)$. The FDIST2 software (Beaumont et Nichols, 1996) was used to identify markers submitted for natural selection. 


\section{Results}

\section{Simulian fauna}

A total of 4244 blackflies were captured during the survey. Two groups of Simulium species have been identified. The savanna group species (Simulium damnosum ss, and S. sirbanum) abundant in Touba and Bouaflé with 2900 blackflies captured, and the forest group species ( $S$. squamosum, $S$. sanctipauli, S. soubrense) present only in Soubré with 1103 blackflies.

\section{Genetic polymorphism of $s$. damnosum s.l populations}

Electrophoretic profiles (Fig.1) obtained after the PCR reveals 33 different alleles in the whole populations. 17 alleles were observed at the 60.1 locus, 12 alleles at the 64.2 locus, 11 alleles at the 7.4 locus and 13 alleles at the H3-4 locus, with an average number of 13.25 alleles per locus. The alleles size vary from $100 \mathrm{bp}$ at the H3-4 locus to $975 \mathrm{bp}$ at the 60.1 locus. A specific allele $190 \mathrm{bp}$ is reveled at the loci 60.1, 64.2 and 7.4, with respective frequencies of $0.38 \%, 0.55 \%, 0.45 \%$. Similarly, the $290 \mathrm{bp}$ allele is reveled abundant to the H3-4 locus with a frequency of $0.58 \%$

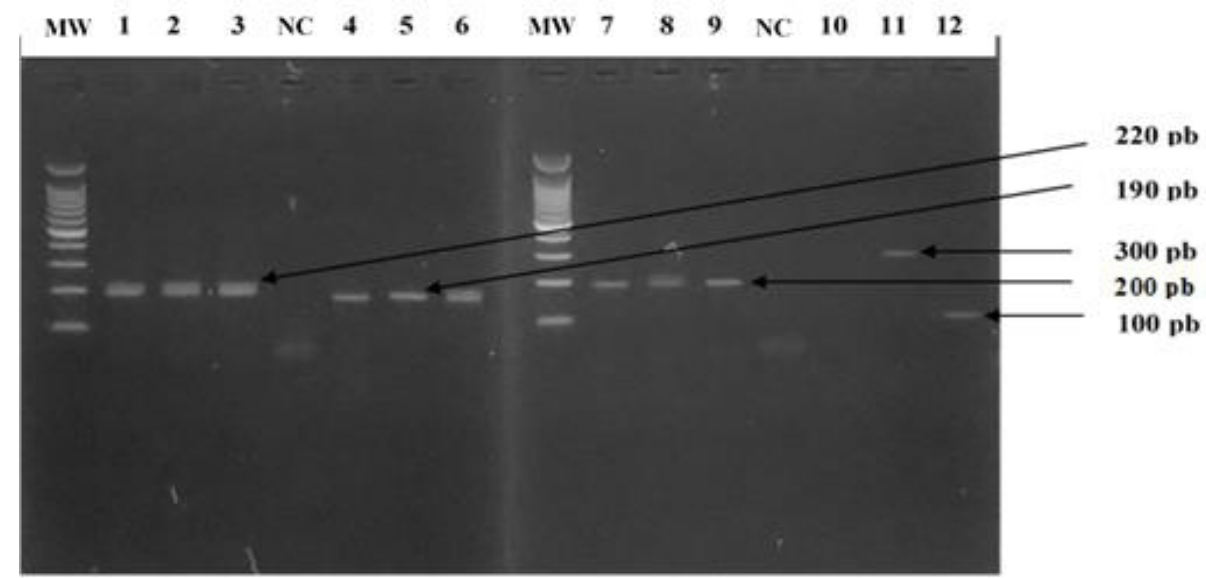

Fig 1: Electrophoregram on $2 \%$ agarose gel.

Abbreviation: MW: Molecular weight marker (72 bp) ; 1, 2, 3, 6, 8: Sample of heterozygous profile ; 4, 5, 7, 9, 11, 12: Homozygous profit sample ; NC: Negative control

\section{Linkage disequilibrium within the three zones}

The exact test of the linkage disequilibrium between all the loci in each sample made it possible to analyze a total of 961 allelic combinations. No significant values were obtained across all populations for any locus combination ( $\mathrm{P}>0.05$ for each pairwise comparison), suggesting that the loci give independent estimate of population genetic parameters. 


\section{Genetic variability among populations}

Mean observed heterozygosity per locus, varied between 0.346 and 0.428 respectively in Soubré and Bouaflé. Which is lower than expected heterozygotes (0.710 for Soubré and 0.576 for Touba) (Table 2). The four polymorphic loci, showed significant deviation from Hardy-Weinberg. Moreover, the $\mathrm{F}_{\mathrm{IS}}$ values were positive at all loci, indicating extensive heterozygosity deficiencies.

Table 2: Genetic diversity and intrapopulation differentiation

\begin{tabular}{|c|c|c|c|c|c|}
\hline \multirow{2}{*}{ Locus } & & Touba & Bouaflé & Soubré & \multirow{3}{*}{$P$-value } \\
\hline & $\mathbf{N}$ & 147 & 151 & 139 & \\
\hline \multirow{5}{*}{60.1} & $\mathbf{n}$ & 8 & 10 & 12 & \\
\hline & $\mathbf{H}_{\mathbf{o}}$ & 0.429 & 0.543 & 0.469 & 0.0139 \\
\hline & $\mathbf{H}_{\mathbf{e}}$ & 0.631 & 0.724 & 0.817 & 0.0239 \\
\hline & FIS $_{\text {I }}$ & 0.321 & 0.251 & 0.426 & 0.0466 \\
\hline & $\mathbf{N}$ & 6 & 7 & 9 & \\
\hline \multirow{3}{*}{64.2} & Ho & 0.282 & 0.377 & 0.260 & 0.0252 \\
\hline & $\mathbf{H}_{\mathbf{e}}$ & 0.480 & 0.680 & 0.721 & 0.0525 \\
\hline & $\mathbf{F}_{\text {IS }}$ & 0.415 & 0.446 & 0.639 & 0.0619 \\
\hline \multirow{5}{*}{7.4} & $\mathbf{N}$ & 8 & 7 & 7 & \\
\hline & Ho & 0.333 & 0.385 & 0.379 & 0.0272 \\
\hline & $\mathbf{H}_{\mathbf{e}}$ & 0.586 & 0.684 & 0.771 & 0.0567 \\
\hline & $\mathbf{F}_{\text {IS }}$ & 0.433 & 0.438 & 0.510 & 0.0625 \\
\hline & $\mathbf{N}$ & 7 & 9 & 6 & \\
\hline \multirow{4}{*}{ H3-4 } & Ho & 0.371 & 0.408 & 0.276 & 0.0264 \\
\hline & $\mathbf{H}_{\mathbf{e}}$ & 0.609 & 0.593 & 0.532 & 0.057 \\
\hline & $\mathbf{F}_{\text {IS }}$ & 0.392 & 0.312 & 0.482 & 0.061 \\
\hline & $\mathbf{N}$ & 29 & 33 & 34 & \\
\hline \multirow{3}{*}{ Moyenne } & Ho & 0.353 & 0.428 & 0.346 & 0.011 \\
\hline & $\mathbf{H}_{\mathbf{e}}$ & 0.576 & 0.670 & 0.710 & 0.0145 \\
\hline & $\mathbf{F}_{\text {IS }}$ & 0.3879 & 0.3616 & 0.5134 & 0.0314 \\
\hline
\end{tabular}

Abbreviation: $\mathrm{N}$ : number of individuals tested in the population $; \mathrm{n}$ : number of alleles $; \mathrm{H}_{\mathrm{o}}$ : heterozygote observed $; \mathrm{H}_{\mathrm{e}}$ : Heterozygote expected ; $P$-value : probability of conformity to the Hardy-Weinberg equilibrium

\section{Genetic differentiation of $S$. damnosum s.l populations}

The exact test for population differentiation indicated that a low genetic differentiation is observed, when comparing F $_{\text {ST }}$ between the three populations (Table 3), suggesting that genotypes of the individuals result from the same gene pool. The overalls FST were $0.025,0.007$ and 0.016 for pairwise populations of Touba and Bouaflé, Touba and Soubré, and Soubré and Bouaflé, respectively. In the same way, populations of Touba and that of Bouaflé are genetically close to from each other $\left(\mathrm{F}_{\mathrm{ST}}=0.025\right)$. 
Table 3: Genetic Differentiation in S. damnosum Populations

\begin{tabular}{lllllll}
\hline Loci & $\mathbf{6 0 . 1}$ & $\mathbf{6 4 . 2}$ & $\mathbf{7 . 4}$ & $\mathbf{H 3 - 4}$ & all loci & $\boldsymbol{p}$-value \\
\hline Touba/ Bouaflé & 0.032 & 0.022 & 0.010 & 0.037 & 0.025 & 0.057 \\
Touba / Soubré & 0.090 & 0.042 & 0.038 & 0.113 & 0.071 & $\mathbf{0 . 0 0 7}$ \\
Soubré / Bouaflé & 0.049 & 0.030 & 0.038 & 0.052 & 0.042 & $\mathbf{0 . 0 1 6}$ \\
Total & 0.057 & 0.031 & 0.028 & 0.067 & $\mathbf{0 . 0 4 6}$ & $\mathbf{0 . 0 2 4}$ \\
\hline \hline
\end{tabular}

\section{Markers under selection}

Analysis of $\mathrm{F}_{\mathrm{ST}}$ between populations of $S$. damnosum s.l, indicates that no microsatellite loci are submitted to the natural selection (Fig. 2). When we are around the median (expected $\mathrm{F}_{\mathrm{ST}}$ under the neutral hypothesis), two (2) markers 64.2 and 7.4 showed low levels of genetic differentiation between populations. In contrast the 60.1 and H3-4 loci showed a moderate level of genetic differentiation, but the $\mathrm{H} 3-4$ locus would contribute more to this genetic differentiation between populations.

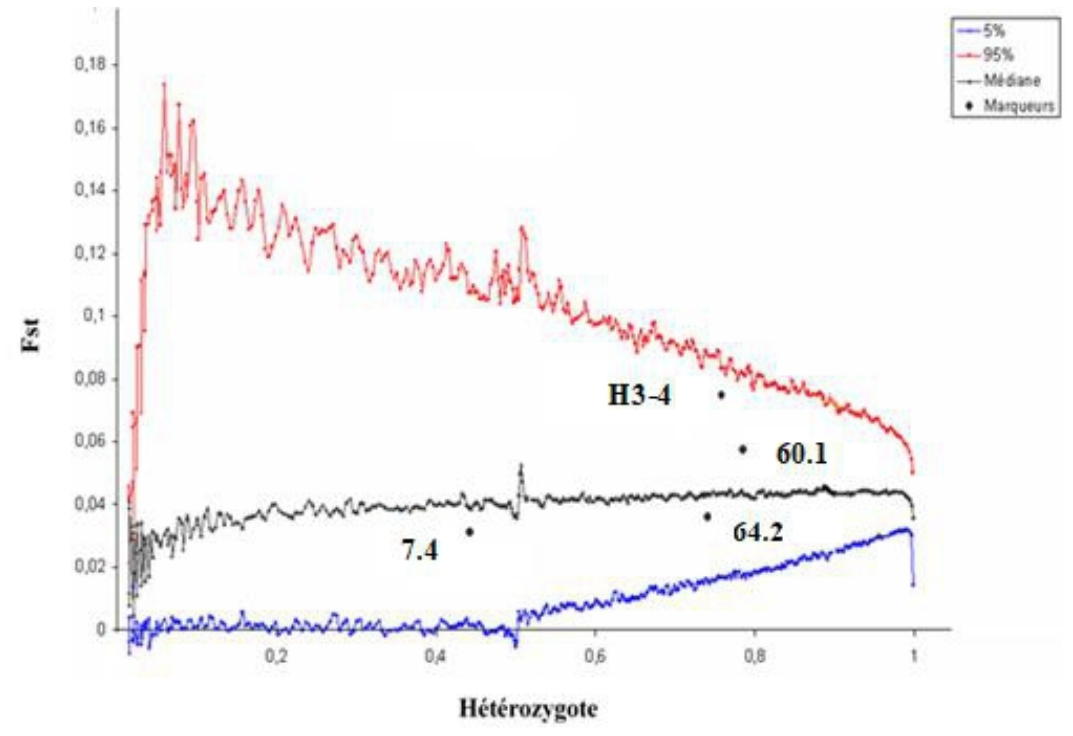

Fig. 2: Expected Fst values for heterozygosity on four (4) microsatellite markers at three (3) populations of Simulium damnosum s.l

\section{Discussion}

All of the blackflies captured in this study belong to the $S$. damnausum $s l$ complex as reported by previous studies in other localities of the country, especially at the ecological station of Taï and the site of the dam of Soubré (Traore et al., 1980 ; Traore and Hebrard, 1981 ; Yapi et al., 2014). Specific identification indicates that savanna species constitute essential of the catches in the sites of Bouafle and Touba. With regard to the site of Soubre, forest species are the only ones encountered. Indeed, Bouafle borders the "V 
Baoule", advanced profound towards the South, in the forest. In relationship with deforestation and declining rainfall in recent decades, we are witnessing a gradual reduction of extent of the wooded areas and southern wet. This induce the progression of the species distribution area of S. damnosum vectors of savanna onchocerciasis towards the south where they substitute, sometimes massively, and more and more durably, to native species wetlands. However, the group of savanna blackflies ( $S$. damnosums, $S$. sirbanum) and savannah $O$. volvulus form one of the most effective couples in onchocerciasis transmission (WHO, 2002).

The microsatellite loci used to evaluate the level of genetic variation, were highly polymorphic in the three populations, ranging from 11-17 alleles per locus. This number is accordance with results obtained in two $S$. damnosum s.l populations study of Mali (Dumas et al., 1998), in which 8-12 mean alleles per locus were found. Also, the few studies of $S$ damnosum s.l at population level using molecular markers (Adjami et al., 2006) indicate, in general, a great interspecific variability. This high level of genetic polymorphism would be a general characteristic in S. damnosum s.l. No linkage disequilibrium between loci was detected in any population, suggesting that the loci give independent estimates of population genetic parameters. Similar studies of other tropical disease vectors corroborate this result. It's about especially works of Acapovi-Yao et al. (2015) on the genetic differentiation and structuration of Glossina palpalis palpalis populations in Azaguié zone (Côte d'Ivoire), and Akré et al. (2015), on the genetic structure of Anopheles nili s.s vector populations of malaria in rural and peri-urban of Côte d'Ivoire.

Genetic analysis of $S$. damnosum s.l populations showed significant deviation from Hardy-Weinberg and significant heterozygosity deficiencies. Such deficiencies would be generated by numerous factor, including inbreeding, population structure and null alleles. Indeed, the analysis of 7.4 and H3-4 markers reveals the failure of PCR amplification was due to point mutation in the primer. So, the fact that some alleles have not amplified at some loci, makes the presence of null alleles is the most explanation for these deficits of heterozygosity. These results are in agreement with the study of Dumas et al. (1998). They also demonstrated the existence of null alleles during their study on the use of microsatellite markers to differentiate two savanna populations in Mali. Also, inbreeding could also be the cause of this deficiency, but it seems unlikely, since such effects should be expected to be evident for all loci (Dumas et al., 1998). Structuration of the population is another cause of the heterozygosity deficiencies observed. Of the three studied sites, two are within the area of OCP control, where blackflies populations have been regularly eliminated through insecticides treatments. If recolonization occurs and is very recent, a Walhund effect could ensue 
(Adjami et al., 2006). This would produce heterozygosity deficiencies, if the colonizing populations are markedly differentiated (Dumas et al., 1998). Another explanation could be the presence of mixed species in these populations. (Estrada-Franco et al., 1992) demonstrated that an excess of homozygotes in anopheles populations was due to mixed species of the Anopheles quadrimaculatus complex, leading to the description of a new species.

The study performed by comparing two by two samples of $S$. damnosum s.l, has shown the existence of a low genetic differentiation between these populations. This result could be explained by high migration rates, estimated from null alleles (Slatkin, 1985). The results obtained in this study confirms the preceding study of Adjami et al. (2006), which tend to show that the migration is an essential characteristic of $S$ damnosum s.l. Also, the high dispersal ability of $S$. damnosum s.l in combination with high migration rates, permitted a genetic mixing which tends to homogenize populations and limit their differentiation. However, mean pairwise F $_{\text {ST }}$ low significance between Western Simulium populations from Côte d'Ivoire, would be due to a probable evolution of the main of invasive $S$. damnosum strains in these localities. This evolution would have occurred during the migrations, which would have favored genetic exchanges between Simulium populations.

The microsatellite markers used in this study do not show natural selection signatures in S. damnosum s.l. populations. However, the H3-4 locus with a moderate differentiation index would be the region of the genome susceptible to be involved in the long term, in a probable adaptation of Simulium to very diverse environmental conditions across its distribution area. This is the approach of (Beaumont and Nichols, 1996), which is based on the idea that in a population, all genome loci have same F $_{\text {ST. Only the loci under }}$ selection derogate from this rule, because the natural selection edit their FST.

\section{Conclusion}

This study showed significant deviation from Hardy-Weinberg and significant heterozygosity deficiencies in the populations of the three localities. Then the hypothesis of a Wahlund effect is also suggested. Also, the study of linkage disequilibrium between loci indicates that, the loci give independent estimate genetic parameters. The H3-4 locus is not systematically involved in the genetic differentiation observed. Since then, only constraints specific to this locus would be at the origin of the differences observed. The presence of null alleles is revealed at this locus. Finally, this locus contributes by the value of its $\mathrm{F}_{\mathrm{ST}}$ to a low genetic differentiation between the populations. Complementary studies will be carried out to deepen knowledge on the genetic structure of populations of this vector onchocerciasis in Côte d'Ivoire. 


\section{References:}

1. Acapovi-Yao, G.L., Pokou, N.D., \& Zakpa, L.G. (2015). Différenciation et génétiques des populations de glossina palpalis palpalis dans la zone d'azaguié (Côte d'Ivoire) à l'aide de marqueurs microsatellites. Science de la vie, de la terre et agronomie REV. CAMES, 03(01), 2424 -7235.

2. Adjami, A.G., Ravel, S., Toé, L., Sanfo, M.S., Bissam, Y., Yaméogo, L., \& Cuny, G. (2006). Spatiotemporal study of genetic variability of simulium damnosum s.l. on the axis Sierra Leone-Guinea -Mali. Thèse de doctorat, Université de Monptelier II, France. (pp 118-26).

3. Akre, A.M., Touré, M., \& Kengne, P. (2015). Structure génétique des populations d'anopheles nili s.s vecteur du paludisme en milieu rural et periurbain de Côte d'ivoire. European Scientific Journal. 11(6), 8577881.

4. Anderson, J.M., Lai, J.E., Dotson, E.M., Cordon-Rosales, C., Ponce, C., Noms, D.E \& Beard, C.B. (2001). Identification and characterization of microsatellite markers in the Chagas disease vector Triatoma dimidiata. Infect Genet Evol. 1, 243-8.

5. Beaumont, M.A., \& Nichols, R.A. (1996). Evaluating loci for use in the genetic analysis of population structure," Proc R Soc Lond B Biol Sci. 263, $619-1626$.

6. Belkhir, K., Borsa, P., Chikhi, L., Raufaste, N., \& Bonhomme, F. (2004). GENETIX 4. 05.2. Logiciel sous Windows TM pour la génétique des populations. [Online] Available: http://www.univmontp2.fr/-genetix/genetix/constr.htm\# (July 10, 2018).

7. Cohuet, A., Dia, L., Simard, F., Raymond, M., Rousset, F., AntonioNkondjio, C., Awono-Ambene, P.H., Wondji, C.S., \& Fontenille, D. (2005). Gene flow between chromosomal forms of the malaria vector Anopheles funestus in Cameroon, Central Africa, and its relevance in malaria fighting. Genetics. 169, 301-11.

8. Duke, B.O.L. (1990). Human onchocerciasis-an overview of the disease. Acta Leiden, 59, 9-24.

9. Dumas, V., Herder, S., Bebba, A., Cadoux-Barnabe, C., Hellee, C., \& G. Cuny. (1998). Polymorphie microsatellites in Simulium damnosum s.l. and their use for differentiating two savannah populations : implications for epidemiological studies. Genome. 41, 154-61.

10. Estrada-Franco, J.G., Ma, G.C., Lanzaro, M., Gwadz, R., GalvanSanchez, C., Cespedes, J.L., Vargas-Sagarnaga, R., \& Rodriguez, R. (1992). Genetic evidence of a species complex in Anopheles pseudopunctipennis. Boletin de la Oficina Sanitaria Panamericana. 69, $219-236$. 
11. Goudet, J. (3003). Fstat Version 2.9.4 : acomputer program to calculate F-statistics," Journal of Heredity. 86, 485-486.

12. Hougard, J.M., Alley, E.S., Yameogo, L., Dadzie K.Y., \& Boatin, B.A. (2001). Eliminating after 14 years of vector control : a proved strategy," Journal Infection Disease, 84, 497-503.

13. Le Berre, R. (1966). Contribution à l'étude biologique et écologique de Simulium damnosum Théobald, 1903 (Diptera, Simulidae). Mémoires ORSTOM. 17, 204.

14. Philippon, B. (1977). Etude de la transmission d'Onchocerca volvulus (Leuckart,1893) (Nematoda, Onchocercidae) par Simulium damnosum Theobald, 1903 (Diptera, Simulidae) en Afrique tropicale. Tropicale et documentation de l'ORSTOM. (pp 308).

15. Prost, A. (1980). Latence parasitaire dans l'onchocercose. Bull world health organ.(pp 923-5).

16. Quilievéré, D. (1976). Contribution à l'étude des caractéristiques taxonomiques, biologiques vectrices des membres du complexe Simulium damnosum présents en Côte d'Ivoire. Travaux et Documents de I'ORSTOM. (pp 307).

17. Ravel, S., Herve, J.P., Diarrassouba, S., Koné, A., \& Cuny, G. (2002). Microsatellite markers for population genetic studies in Aedes aegypti (Diptera: Culicidae) from Cote d'Ivoire : evidence for a microgeographic genetic differentiation ofmosquitoes from Bouake. Acta Trop. 82, 39-49.

18. Ravel, S., Monteny, N., Velasco Olmos, D., Escalante Verdugo, J., \& Cuny, G. (2001). A preliminary study of the population genetics of Aedes aegypti (Diptera :Culicidae) from Mexico using microsatellite and AFLP markers. Acta Trop. 78, 241-50.

19. Sightsavers. (2011). Elimination de l'Onchocercose : plan d'action accéléré dans 24 pays recevant le soutien de Sightsavers 2011-2021. 207(544). 38 -110.

20. Simard, F., Fontenille, D., Lehmann, T., Girod, R., Brutus, L., Gopaul, R., Dournon, C. and Collins, F.H. (1999). High amounts of genetic differentiation between populations of the malaria vector Anopheles arabiensis from west Africa and eastern outer islands. Am. J. Top. Med. Hyg. 60, 1000 -1009.

21. Slatkin, M. (1984). Gene flow in natural populations. Annu. Rev. Ecol. Syst, 16, 393-430.

22. Solano, P., de La Rocque, S., Cuïsance, D., Geoffroy, B., De Meeus, T., \& Du Vallet, G. (1999). Intraspecific variability in natural populations of Glossina palpalis gambiensis from West Africa, revealed by genetic and morphometric analyses. Med Vet Entomol. 13, 401-7. 
23. Traore, S., \& Hebrard, G. (1981). Les capacités vectrices naturelles des femelles du complexe Simulium damnosum (Diptera, Simuliidae) au niveau de la station écologique de Taï. Doc ronéo OCCGE/ORSTOM. (pp 81).

24. Traore, S., Philippon, B., \& Hebrard, G. (1980). Bioécologie et caractéristiques vectrices naturelles des femelles du groupe $\mathrm{S}$. soubrense - S. sanctipauli sur le bas-Sassandra (site du barrage de Soubré). Doc Techn OCCGE. 7556, 80.

25. Simaro S., Koffi M., Touré M., Yao P., Ahouty B., \& Tidou A.S. (2019). Capacité Vectorielle et abondance des populations du complexe Similium damnosum dans trois faciès épidémiologiques à l'ouest de la Côte d'Ivoire. Afrique SCIENCE.15(2) ,16-23.

26. WHO / APOC. (2009). Rapport de la $29^{\text {ème }}$ session du Comité Consultatif Technique (CCT), Ouagadougou. (pp 115).

27. WHO. (2002). Module de formation des techniciens entomologiste à la prise en charge et à la supervision des activités entomologiques de lutte contre l'onchocercose. (pp 15).

28. Yapi, Y.G., Traore, F.D., Coulibaly, D., \& TIA, E. (2014). Etude contributive à la connaissance des populations de simulies dans la commune de Bouaflé, Centre-Ouest de la Côte d'Ivoire. Int.J. Biol. Chem. Sci. 8(6), $2540-2551$. 